\title{
The texture of agency: an example of culture-contact in central Australia
}

\section{ALISTAIR PATERSON}

\begin{abstract}
A regional historical archaeological analysis of Strangways Springs Station, northem South Australia, reveals the evidence for interaction in the period 1850-1900 between Aboriginal people and newly arrived European pastoralists. The evidence from campsites and worksites demonstrates differential Aboriginal involvement in the nineteenth century pastoral domain. The nature of cultural interaction changed as the pastoralists adapted and transformed their economic and social behaviour in response to the harsh Lake Eyre Basin environment and to economic and technical parameters related to the fledgling pastoral industry. The case study shows that archaeological and historical evidence each provide different perspectives on past culture contact and human agency.
\end{abstract}

\section{Introduction}

The aim of this paper is to demonstrate how cross-cultural interaction is characterised by different types and degrees of interpersonal engagement, and how historical and archaeological evidence each provide different insights into contact-period agency. The case study is of Strangways Springs Station in the southwestern Lake Eyre Basin, northern South Australia (Figure 1), where from c. 1860 interaction between Aboriginal people and Europeans occurred primarily in the pastoral domain. The historical archaeological evidence from this place is presented under several headings: spatial patterning; labour and economy; social worlds and distinctions; knowledge, power and law; and in two biographies of Aboriginal workers. Each topic considers both individual and group agency by focussing on the evidence for differential indigenous involvement in the pastoral domain. For simplicity the discussion is one-sided, focussing almost solely on Aboriginal people. Despite this, both sides of the cross-cultural interaction at Strangways Springs are evident.

As archaeological records are the cumulative result of the actions of individuals the concept of agency is often central to archaeological interpretation. The use of the term in processual and post-processual literature has lead

Centre for Archaeology, University of Western Australia, 35 Stirling Highway, Crawley, 6009, Australia.

Email: paterson@cyllene.uwa.edu.au

\begin{abstract}
Copyright of Full Text rests with the original copyright owner and, except as permitted under the Copyright Act 1968, copying this copyright material is prohibited without the permission of the owner or its exclusive licensee or agent or by way of a licence from Copyright Agency Limited. For information about such licences contact Copyright Agency Limited on (02) 93947600 (ph) or (02) 93947601 (fax)
\end{abstract}

to a blurring of the theoretical implications of its use, leading a recent publication to ask whether the agency concept is useful (Dobres and Robb 2000:13). Certainly the term 'agency' is used broadly; an historical overview of the many different uses of the term 'agency' is provided by Dobres and Robb (2000 Ch. 1), and expressed by Dornan: "Indeed, agency has alternatively been equated with the individual; individually unique cognitive structures; resistance to social norms; resistance to power inequalities; the capacity for skilful social practice; freedom from structural constraints; and free will" (2002:304). With this range of meanings it is necessary to explain what I mean by agency in this paper. The following discussion explores links between the reported lives of historically described individuals and archaeological records of cumulative individual and group behaviour - testing how the past actions of individuals and groups are represented in the different evidence in this case study. Different evidence provides different insights into individuals and groups according to their gender, age, type of work, and degree of contact with Europeans. Thus I am interested in how the actions of individuals and different groups in society are reflected in archaeological and documentary records.

In addition, this archaeology of culture contact has the potential to provide new knowledge. For colonial central Australia we have some knowledge of recent - particularly post-1900 - contexts of cultural interaction (for example Rose 1991; Baker 1999; Rowse 1998), but our historical knowledge of earlier phases of cultural interaction in the nineteenth century is poor.

\section{Strangways Springs Station}

Tourists seeking desert landscapes and a sense of remote Australia travel the Oodnadatta Track skirting the edge of Lake Eyre South, passing across gibber plains, dune fields, scrubland and grass plains. This was the route of the Ghan Railway; abandoned ruins of railway stations and pastoral settlements fringe the track. The climate is extreme, freezing on winter nights and rising to $50^{\circ} \mathrm{C}$ in summer. Today's population is concentrated at small communities like Marree, Oodnadatta and Port Augusta.

Prior to European arrival, Aboriginal settlement throughout the region was more scattered than today. Despite Pleistocene occupation in arid Australia (Smith 


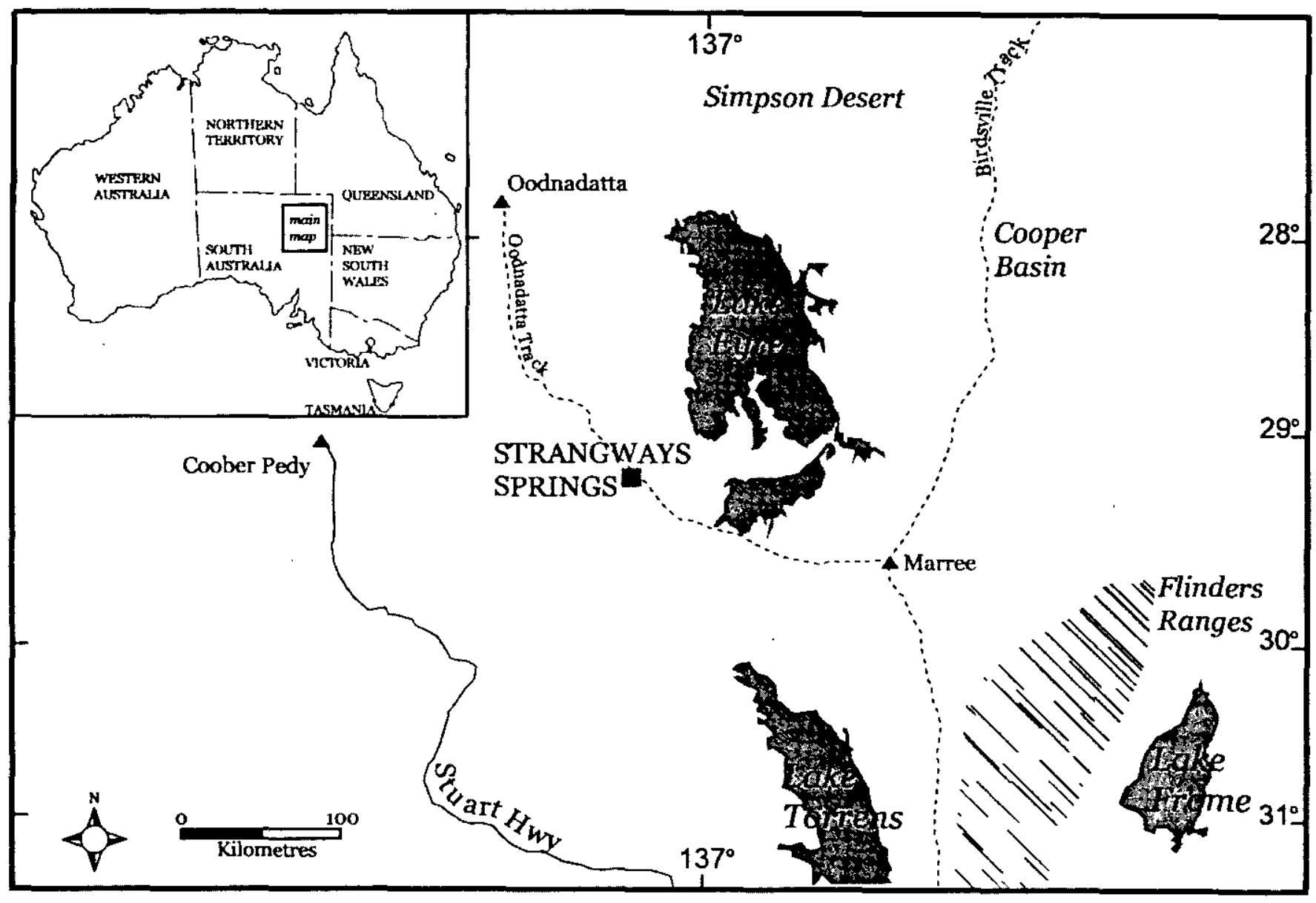

Figure 1. Location of Strangways Springs, south-western Lake Eyre Basin, northern South Australia.

1987, 1989; Veth 1989, 1993) most archaeological evidence indicates human occupation throughout the southwest Lake Eyre Basin only during the last 3000 years (Davidson 1983; Hercus and Clarke 1986; Wasson 1986; Hughes and Lampert 1980), particularly the last 1000 years (Lourandos 1997:184; Florek 1993) when the environment was essentially the same as the present. Archaeological evidence includes campsites, burials, quarries and knapping floors, stone engravings and arrangements. The remains of past occupation mostly occur as surface assemblages and deflated deposits along dune crests and flanks. Surveys indicate the preference of past settlement was for sandy surfaces close to creeks (particularly waterholes) and artesian springs (Hughes 1981a, 1981b; Hughes and Hiscock 1981; Hughes and Lampert 1985; Florek 1993). Inter-site variability may reflect seasonality, when different subsistence tactics were employed at spring (dependable) and non-spring (reliant on rainfall) water sources (Florek 1993). Aboriginal life prior to European settlement was not isolated as trading routes connected Lake Eyre to neighbouring country (McBryde 1987; Hercus 1971, 1980). Trade of material, such as Anna Creek grindstones and Flinders Ranges ochre, and information provided a forum for inter-group meetings. Historical descriptions of armed trading expeditions for ochre indicate trade continued in the early contact period despite colonial attempts to prevent it.

European settlement followed 1850s' explorations. The pastoral settlement of the earliest stations from 1862 onwards - Strangways Springs station was one of the earliest - was the first sustained interaction of European settlers with Aboriginal people of the Lake Eyre Basin. It was also an early step in the continentwide takeover of Aboriginal country, followed by the colonisation of central and northern Australia. The early pastoral ventures encompass the first years of sheèpbased pastoralism in this part of central Australia. From the late 1880 s onwards there was greater reliance on cattle; today all pastoralism in the region is cattle-based. Other factors accompanied these events. The introduction of sheep and cattle altered delicate artesian ecosystems resulting in increased competition by both humans and animals for water resources. The result of the cessation of Aboriginal fire management regimes - due to the presence of pastoralists - on the environment in this region is unclear. Disease, particularly influenza, caused widespread loss of Aboriginal life in the late nineteenth century and earlier epidemics seem likely (GRG 52/7/6:762-4, 7 July 1890).

The research that forms the basis of this discussion was conducted between 1994-1999 during a regional 
archaeological study (Paterson 2000a, 2000b, 2003 forthcoming). These sources need to be consulted to support assertions made in this paper. Following Lightfoot (1995). in this research a model for pre-contact Aboriginal settlement was generated to provide a baseline to compare to later periods. This was based on analyses of surface assemblages and on previous research in the region (references above). Archaeological evidence of the post-contact era includes pastoral activity areas (work sites, outstations, station improvements such as bores and fences) and more permanent settlements (such as the head station at Strangways Springs). This discussion is based on evidence from 64 sites in the study region, derived from both surface and excavated assemblages (Paterson $2000 \mathrm{a}) .^{1}$ As most sites were unstratified, a challenge for this research was to confidently identify the age of Aboriginal sites, particularly for the historic period sites. The data discussed here are from assemblages where there is strong evidence for post-contact use. Related research into pastoral industries by the author and colleagues exists (Gill, Paterson and Japanangka Kennedy 2002; Gill and Paterson forthcoming).

Historic sources used in this research were primarily letters between station managers and owners: this paper focuses on letters from two station managers - Julius Jeffreys (early 1860s) and John Oastler (early 1860 s to c.1908) (MLSA, PRG 27) ${ }^{2}$ Other sources were newspaper and magazine accounts, police records (SRSA, GRG 5 ), the Protector of Aborigines records and Aborigines Office files (SRSA, GRG 52/7), explorers' accounts (Stuart 1865; Babbage et al. 1858; Howitt 1859; Warburton 1988; Gregory 1906) and ethnographies (Spencer and Gillen 1899, 1912; Basedow 1920; Elkin 1934).

\section{Spatial patterns}

This section details how Aboriginals and Europeans at a site and regional level used different places. Settlement patterns reflect changes in pastoral work over time, defining an early phase (from 1862 until c.1882) and later phase (from 1882 onwards) of pastoralism. The primary difference between the two phases involved the management of water resources, chiefly wells and artesian bores constructed during the early 1880 s. Fencing

1. Site codes use an alphanumeric system. The alphabetical prefix indicates location (such as ' $\mathrm{S}$ ' for Strangways Springs) or transect (such as site 'Al' for the first site recorded during transect $A$ ). The number in the ' $S$ ' site codes is the lowest feature number assigned during field recording (site $S 240$ began at the 240th feature recorded at Strangways Springs). Features within a site were given a further numerical code (e.g. 'Al.1'). Records related to this research are held by the author and the Department for State Aboriginal Affairs (South Australia).

2. Most primary material is in the Mortlock Library of South Australiana (MLSA) and the State Records of South Australia (SRSA). also played in important role in the shift from permanent waters to back blocks.

During the earliest years of the station the pastoralists had limited knowledge of local resources in the semi-arid environment. Additionally, there was no technological ability to access subterranean artesian waters at this time. Most settlements (the Strangways Springs' headstation and numerous outstations) were located at naturally occurring artesian springs near to herbage and/or grasslands for grazing. Some outstations were located further from the head station at more ephemeral waters and grasslands. Given the limitations of this environment, it is not surprising that initial pastoral settlement mimicked the pattern of pre-contact Aboriginal settlement, although social and cultural factors influencing settlement patterns existed in addition to environmental parameters. For example, the pastoralists' letters indicate Aboriginal people provided information about the location of water and pastures, and reported where rain had fallen on a remote part of the station (or beyond). The role of Aboriginal knowledge is explored below.

The pastoral system comprised a headstation - commonly the best-known site in the modern landscape as is the case with Strangways Springs, a tourist destination of evocative stone ruins - and a network of outstations and other worksites. These are explained below. Archaeological deposits at Strangways Springs headstation cluster around in the station buildings, but the most extensive assemblages at Strangways Springs derive from pre-contact and post-contact Aboriginal settlements located around the many small artesian springs. The archaeological record indicates that post-contact Aboriginal settlement at the Strangways Springs increased in the historic period with the presence of the largest historic-era Aboriginal camps; and reveals the degree of access to new material culture, and changes in Aboriginal lifeways due to rationing and pastoral work (Paterson 2000a).

Phase 1: $1860 \mathrm{~s}-1880 \mathrm{~s}$. In the earliest years of the station work occurred at Strangways Springs head station, yet the most frequent sites were outstations. During good seasons, the station manager would keep two large flocks (c. 2500 sheep in each) at individual outstations (Oastler 28 July 1868). During 'indifferent seasons' the flocks were stationed at more permanent artesian springs, however the stock would often consume all the feed within travelling distance of the springs, causing significant flock loss. Outstations were simply constructed from local materials (timbers, brush, grass) and hand-wrought nails. Stockyards were enclosures of stacked cut scrub which, with an attentive nightshift shepherd, protected the sheep from native dogs and Aboriginal hunters. The dayshift workers pastured the sheep close to the outstation in separate flocks. The network of outstations reduced stock loss from disease and starvation but it was very labour intensive. As the station managers and owners were mainly British and Scottish they created a local expression of an imported tradition of animal husbandry. 
(However, most of the shepherds were Aboriginal as explored below.) The historian Collier (1911:210-212) described the work at outstations:

Every morning the shepherd set out with the flock...At sunset he returned [and] resigned them into the hands of the night-watch-man...the occupation was considered the lowest kind of labour on the station.

Other workers at outstations included cooks (termed 'hutkeepers') and boundary riders who, in the era before fences, prevented sheep from wandering. However, as in much of south-eastern Australia, this era before fencing passed; by 1910 Bean could state "Even the tradition of them [the shepherds] has almost gone from the 'inside' country" (1910:50).

The presence of British and Aboriginal people at outstations is indicated archaeologically. This is documented in elsewhere (Paterson 2000a, 2000b). For example, one outstation (site N3) had material culture from the $1860 \mathrm{~s}$, stone tools, glass tools and ochre around fireplaces outside a simple wooden hut, while inside the hut were clay pipes, clothing parts (belts, buckles, shoe parts), bottles (commonly for food flavourings and opiate medicines, not alcohol), equipment such as shear blades, and food remains (sheep and kangaroo). An Aboriginal campsite overlooked the hut and brush stock- yards from a neighbouring dune; here were found glass and stone tool making areas, and hearths with sheep remains. These findings supplement station manager letters that indicate the outstations were working sites for Aboriginal male and female shepherds as well as European shepherds and hutkeepers. The letters describe outstations as typically occupied for two to four months and as places where a range of labour intensive activities occurred. During lambing seasons increased surveillance and care of sheep and lambs was required. Aboriginal and European workers were provided with limited rations (flour, tea, sugar, tobacco and meat) brought out from the headstation. This attracted Aboriginal visitors who sometimes involved the Aboriginal station workers in social events. During these events the European pastoralists anticipated theft and violence; they sometimes responded to perceived threats with gunfire. On other occasions white shepherds participated in social events:

The same night the Blacks were camped at our Worley within six feet of the sheep. They had a carrobberry[sic] to announce themselves. [The white men] Jones and King joined in it, I went to bed. (Jeffreys 1866)

In addition to outstations, specialist work camps existed for scouring and shearing wool. These also had associated residential campsites (i.e. site S355) for

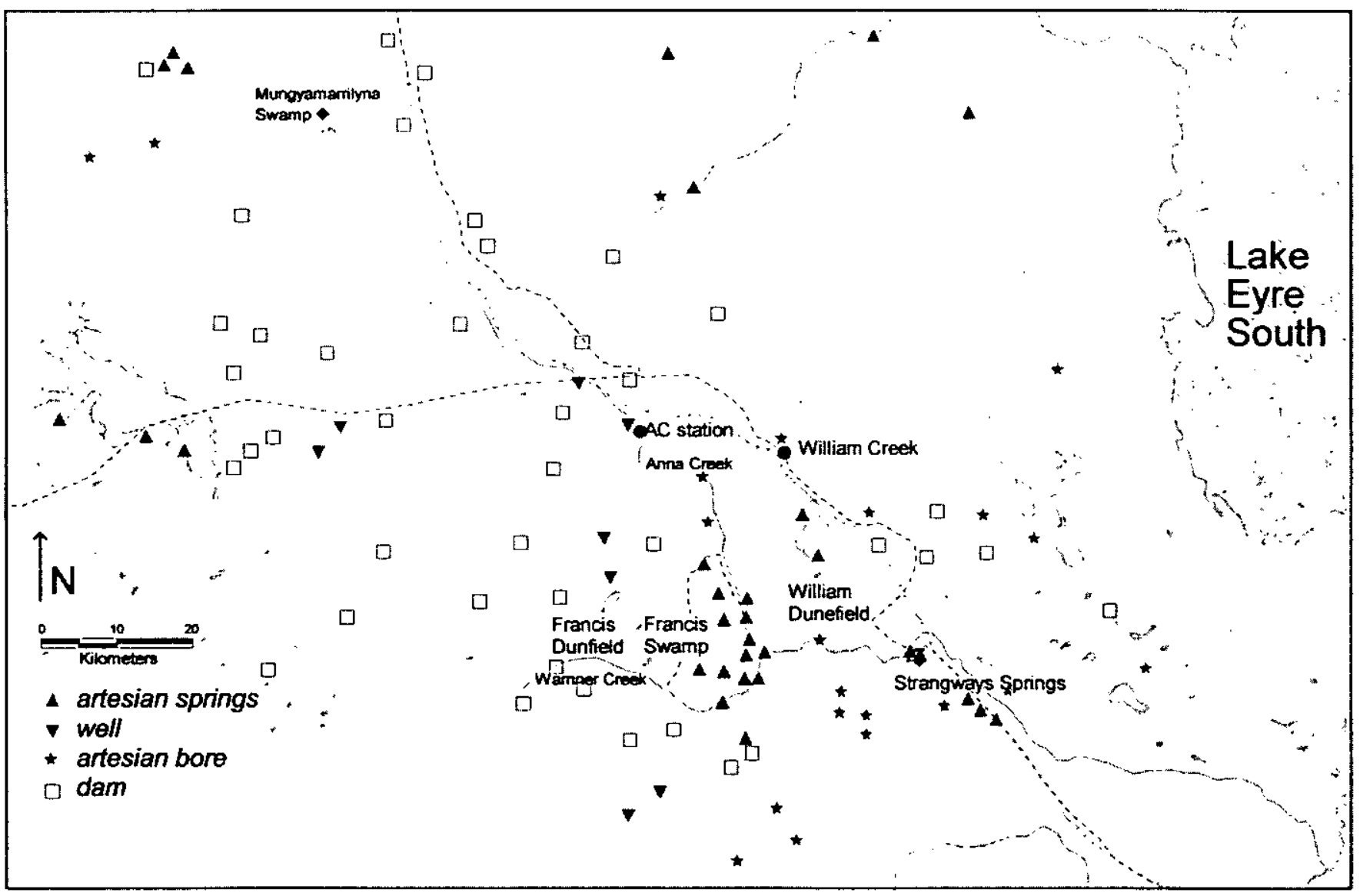

Figure 2. Study area showing 1.) naturally occurring artesian water (mound springs) and 2.) the location of bores, wells and dams established after 1882 . 
Aboriginal workers. Spatial analysis of these sites focused on identifying activity areas, for example, tool making, food preparation and consumption areas, while building material indicated Aboriginal residential structures, made from mulga and sometimes canvas (indicated by grommets). Certain sites were associated with both Aboriginal and European workers, such as places for shepherding, scouring, lambing, dogging (hunting dingoes), tracking and fence repair. Europeans solely occupied other sites, particularly shearing outstations. This describes the pastoral system during the early years of the station.

Phase 2: $1880 \mathrm{~s}-1900$. The second phase at Strangways Springs involved several changes. During droughts between 1864-1867 neighbouring stations were abandoned and suffered financial losses. At Strangways Springs Station loss was partially offset by the low level of capital expenditure. That was to change in the last two decades of the nineteenth century. New pastoral technology, better transportation - with a railway line replacing overland bullock drays, donkey trains and horse travel from Port Augusta, a hazardous 600 kilometre journey to the south - and increased expenditure made it possible for the pastoralists to better regulate water resources and the spatial organisation of the pastoral industry. The size and number of sites from this era overwhelms that of earlier sites. In this period pastoralists constructed wells and artesian bores in areas remote from the natural artesian springs that had proven to be irregular and were often befouled by stock. Large fenced paddocks were built to protect stock from predators; this reduced the need for shepherds. This is reflected in the archaeological record, which demonstrates a shift from the artesian spring country into the dunefields and semi-arid pastures (Figure 2). While there is little evidence of expenditure in the first decades of the pastoral settlement, sites from the 1890s onwards included larger material more readily transported by rail. For example, the woolsheds site on Anna Creek (sites A6, A8 and A9) included boilers, castiron ranges, windmills, metal tanks and metal troughs. The later phase is characterised by more permanent worksites, with fences, metal yards and stone buildings.

To summarise this locational evidence, in the early contact era pastoral work sites were located near the same places Aboriginal people used prior to contact, while some Aboriginal settlement focused at pastoral work sites and rationing sites, or existed 'outside' the pastoral system. The second phase provides a material record of Aboriginal people living at the new, larger outstations; and in larger camps at the headstation which may reflect increased reliance on government rations, as explored below.

\section{Labour and economy}

An inexpensive workforce existed for the pastoralists whose dependence on Aboriginal labour is suggested in their letters and demonstrated at early pastoral sites by strong archaeological signatures of Aboriginal presence. Aboriginal work was full-time (shepherding, bullock driving, translating, animal husbandry), seasonal (lambing and wool-washing) or temporary (message delivery, providing climatic and environmental information, negotiating with Aboriginal people outside of the pastoral domain for seasonal labour and environmental information). The timing of work was known by Aboriginal people as expressed by station manager John Oastler: "Black lamb minders have come back as they promised. And I will do my upmost with their help to get a first rate lambing" (Oastler 19 Jan. 1867).

Both male and female Aboriginal workers are described; males laboured (such as building outstations) and cared for animals (sheep, horses and bullocks), while females shepherded the more populous smaller animals (sheep and goats). Both males and females conducted manual work near the head station, such as wool washing. Both were shepherds at outstations, sometimes without Europeans. Some - if not most - of the most commonly referred to workers were indoctrinated to pastoral work as children. The family unit was common at outstations as often several families shepherded together.

Rationing was central to the economic system at Strangways Springs Station, as workers were provided with food when working, the most popular with both Aboriginals and Europeans being fresh beef. The archaeological record indicates that by the last two decades of the nineteenth century canned meats (fish and beef) were consumed in Aboriginal camps located at pastoral work sites. Other goods in Aboriginal camps were tobacco (claypipes), clothing (buttons and buckles), cooking vessels, metal implements (often broken shear blades) and a small amount of ceramic plates and cutlery located in food preparation and consumption areas. To a smaller degree, the colonial administration provided a limited range of foods and commodities for the old and infirm who resided at the headstation. Describing Central Australia from the 1890 s onwards Tim Rowse states that rationing was 'a pervasive institution of Central Australian colonialism [which began] to replace violence as a mode of government. Pastoralists and missionaries were learning the value of rationing as a way of rendering cross-cultural relationships peaceful and predictable' (1998:7).

The archaeological record demonstrated the amount of goods available to Aboriginal people and Europeans within the pastoral domain. Figure 3 shows 'assemblage richness' (adopted from Kirch 1992) - an ordinal numeration of different types of archaeological evidence at each site. These were: bottles, telegraph equipment, window glass, glass tools/manufacture, clothing, clay pipes, structural material, food containers, other containers, cooking equipment, ceramics, pastoral equipment, bullets, horse equipment, miscellaneous metal, stone tools/manufacture, food processing/preparation equipment, food remains, ochre and hearths. The sites are organised by distance from the headstation, which in the 1800 s was the point of entry into the pastoral system for 


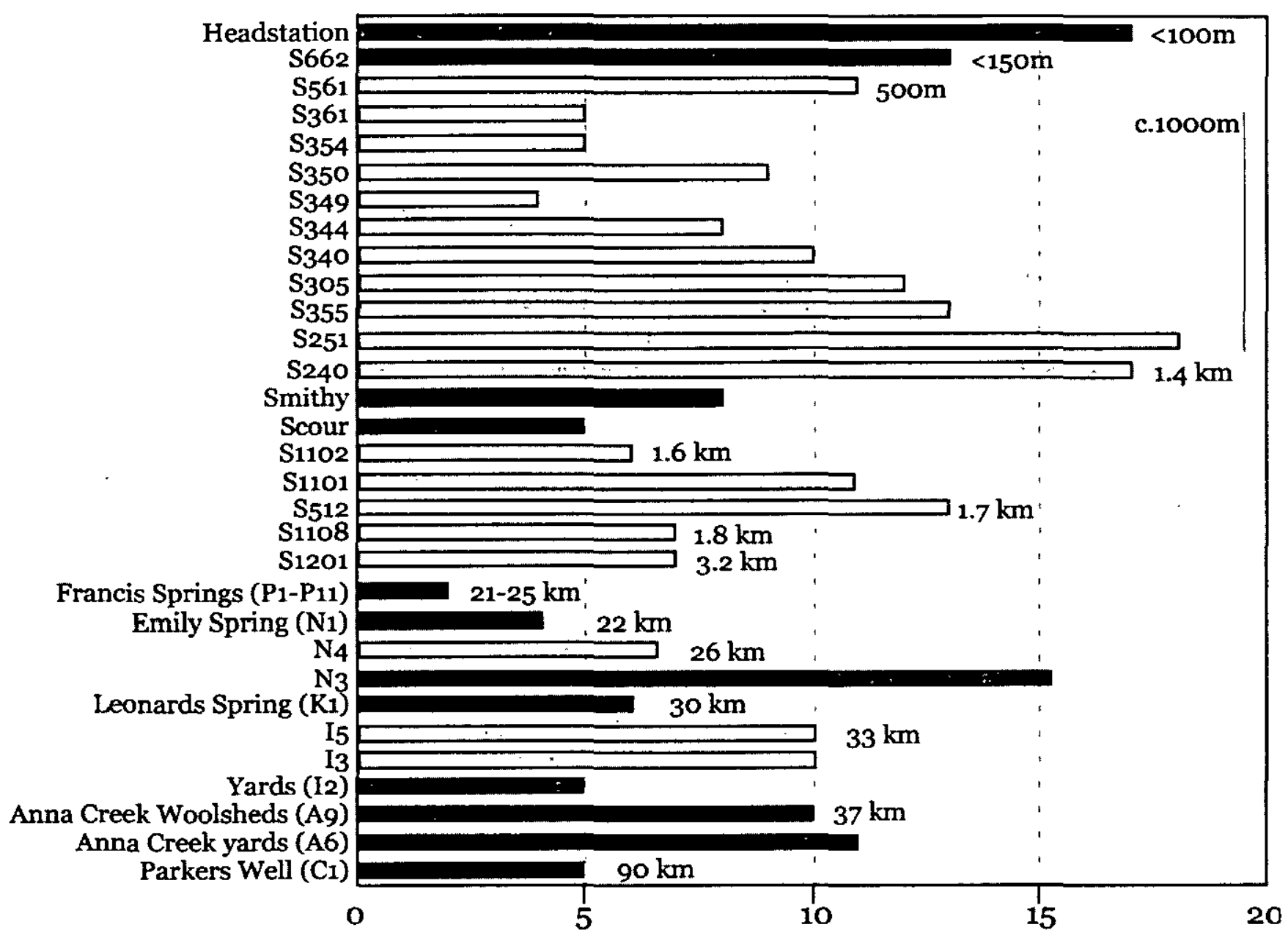

Range of artefact classes

Figure 3. Assemblage richness for selected sites. 'Range' is the number of different artefact classes. Grey infill indicates sites with a primary role as pastoral sites (some including occupation) and white infill indicates sites interpreted as Aboriginal camps. Black infill: 'springs' refer to archaeological sites at artesian springs; S662 may include main refuse disposal deposits from the head station. The sites are ordered by distance from Strangways Springs ('S' prefix) with distance indicated at the right of the columns.

European material culture. The selected sites in the figure were the largest sites recorded that related to the pastoral station, including campsites and worksites at the headstation (S-prefix) and more distant outstations (P1-C1).

Did Europeans have a greater range of items than Aboriginal people? Figure 3 suggests that Aboriginal communities near the headstation and primary worksites had access to a similar range of materials as Europeans. The items at Aboriginal camps S251 and S240 were as diverse as any European camp; while the rationed camp (S561) was nearly as diverse as the European houses (S662). Specialist worksites (such as the Scour and Smithy) and outstations at water sources (P1-P11, N1, K1) were the least diverse. Outstations away from water resources were diverse $(\mathrm{C} 1, \mathrm{~N} 3)$. Some contact era Aboriginal campsites were less diverse than those at the headstation (N4, I2, C1), others were not (I3, I5). These last two sites, and site N4, were located at large campsites overlooking pastoral outstations and suggest the movement of goods into Aboriginal camps only loosely affiliated - perhaps by kin - with pastoral workers (Aboriginal or European). Sites A9 and A6 were large, permanent outstations for shearing sheep used over many seasons and would have been used by mainly European shearers - yet were less diverse than rationed Aboriginal camps at Strangways Springs headstation.

These results upset some simple expectations about the movement of goods into Aboriginal society. The diversity of goods decreased at some - but not all Aboriginal camps more distant from the headstation. However, the rationed camps were larger and more diverse than any other Aboriginal camps in this study. 
This suggests that Aboriginal people in ration camps were accessing a greater range of material than suggested in historical descriptions of rations.

Did occasional work change Aboriginal subsistence? The letters indicate that Aboriginal people in sufficient numbers were on hand to work, and that during drought there were more prospective workers than available work. Pastoral work opportunities, with the exchange of rationed food and commodities for labour, could be viewed as an extension of pre-contact subsistence patterns, similar to when rain fell and more food was available.

The pastoral domain described here reveals several types of Aboriginal work at Strangways Springs station and consequently differing degrees of involvement between white and black. The social implications of this are considered below.

\section{Social worlds and distinctions}

In the historical and archaeological records of the pastoral domain two groups of Aboriginal people are clearly distinguished. Put simply, Aboriginal people were described by pastoralists as either 'station' or 'wild' ('strangers' is another term the pastoralists used). As described above, while some work was permanent, most was occasional - thus the boundary between the two categories was permeable. In the archaeological record the distinction between 'station' and 'strangers' is less clear: it is difficult to know whether Aboriginal artefacts were from workers, residential families of workers, or visitors. However, assemblage richness broadly reflects the degree of involvement in the pastoral domain. A greater range and quantity of material culture from European origins is assumed to indicate access to European goods. Additionally, the record reveals that the location of post-contact Aboriginal settlement in relation to European/pastoral activities varied over time. There was also movement of European material culture (commonly glass and metal objects having undergone modification) to areas of Aboriginal settlement removed from pastoral activities.

Aboriginal involvement in the pastoral domain depended not only on work availability, but also cultural obligations. Work was sometimes interrupted by cultural events, such as Aboriginal pastoral workers being invited by Aboriginal 'strangers' to be involved in ceremonies, particularly initiation.

Aboriginal people partially accommodated within the pastoral domain were potentially able to maintain regular access to traditional country, for, as explored below, the pastoralists may have resisted visiting Aboriginals. This domain provided opportunities, such as access to work, rations and some medical care. This in part was a measure of limitations, as the station could only accommodate a certain number of Aboriginal workers - others had to fend for themselves or access the small amount of government rations distributed elsewhere in the region. Fences may have restricted access to country, although fence maintenance was conducted by Aboriginal workers (see below). The relationship between Aboriginal workers and pastoralists was emphasised in 1886 and 1889 , when Aboriginal pastoral workers and their kin moved with the Europeans to the new headstation at Anna Creek.

To some degree Europeans were integrated into Aboriginal society and into indigenous explanations of the world. While there is little historical evidence for this, one station manager - John Oastler - describes in his memoirs his close relationship with Aboriginal workers, and that he was called 'Mootabata' (father). His account of forty years on the station demonstrates his sustained working relationship with key Aboriginal workers and their families at Strangways Springs.

Although it was not directly described, sexual relations would have played a role in cross-cultural relationships at Strangways Springs. Oastler recalled one occasion in the $1860 \mathrm{~s}$ when:

A flock of lambing ewes had been placed... with the black shepherds [when] a white man, a traveler with a horse, had virtually taken possession of the Out Station, refusing to allow Sambo and his lubra to return with his dray and bullocks (you must understand that the lubra was the attraction to this unprincipled man)...there was nothing for it but to buckle on my revolver and to proceed to the sheep station...(1908)

McGrath (1987:3), describing pastoral work in Queensland, stresses that power relationships between pastoralists and Aboriginal people were based in part on access to Aboriginal women for sex. She explains that this was made possible through violence and through exchange of items such as flour, blankets and clothes (see also Reynolds 1972, Ch. 5). As described above, female workers were present at outstations and the headstation, while there were very few European women ever described.

\section{Knowledge, law and power}

Aboriginal knowledge and practices in part dictated the spatial parameters of the initial pastoral domain. For example, station manager Oastler's knowledge of annual regional weather patterns was based on information from Aboriginal informants (Oastler 23 Feb. 1867). This type of climatic knowledge was utterly essential in this marginal environment. However the Europeans did not adopt other aspects of Aboriginal practice, such as regular fire management. Perhaps not surprisingly, over time the pastoralists' dependence on Aboriginal knowledge (but not labour) decreased. This shift was clear during the later phase of pastoralism described above, presumably resulting from the pastoralists' transformation of the pastoral landscape - described throughout country Australia as 'making improvements' (Strang 1999). Less Aboriginal knowledge was required after the reorganisation of the industry around newly constructed artesian bores and wells. The construction of fenced 
areas to regulate native and introduced animals meant less work for shepherds, and more work for Aboriginal rabbit and dingo hunters.

The pastoralists also perceived of themselves as lawchangers, as remembered by Oastler:

To break these wild tribes into something like obedience, and to teach them the law of ownership and property, and that their laws must give way to white mans' law, were the most difficult tasks. (1908)

The Europeans introduced a new legal system that privileged the pastoral lessee over Aboriginal people, and provided the basis for a pastoral domain where Aboriginal access to culturally important places (such as Strangways Springs) was restricted by the pastoralists' resistance to 'strangers': "we have seen a great number of strange blacks about here at times and although they are anything but pleasant to look upon in their paint and filth they have not molested us as yet" (Jeffreys 7 July 1866). The maintenance of colonial law was in the hands of the pastoralists. In 1866 the Attorney General wrote that the station managers "may hear and determine in a summary way charges against aboriginal natives [for] offences to which the punishment of death is not attached and sentence to imprisonment for twelve months" (Jeffreys, early 1866). However, law enforcement depended on distance from the resources of the head station; for example in 1866 when foreign Aboriginal groups on the distant Douglas River were hunting station sheep the manager had to move the flocks because they were too far away to defend (Jeffreys 5 Mar. 1866).

In the first decades of the pastoral system there were numerous incidents of Aboriginal raids on outstations, and threats against both white and black shepherds. Not all violence from 'strangers' was to obtain goods. For example, descriptions of 'pinyaroo' - revenge mission (Howitt [1908]1996:178) - visits to station sites indicate how Aboriginal society crossed into the pastoral domain. Oastler described the pinyaroo as:

a large group of [armed] natives... which proceeds to the camp of the condemned man to vindicate their law, when no doubt they feel (no matter how outrageous such feeling appears to us) that they are good and true men, who have but done their duty (Oastler 1908).

When this behaviour threatened Aboriginal workers within the pastoral domain, station managers responded with force. Oastler recalled that:

In dealing with the wild or semi-wild aborigines I have always held this in mind, never being over-harsh with them, but by being 'suaviter in modo, fortiter in re' [Translation: Gentle in manner, resolute in deed], I hope to be able to show that I may have prevented much bloodshed, and perhaps rendered the State more or less some form of service. I would like to state here that in all the doings of these wild natives they have distinct laws, and they carry them out. That they are revolting and wicked to the last degree, to our mind, goes without saying, although to their way of reasoning the very essence of justice (Oastler 1908).
Thus two bodies of law existed and competed. This accords with Rowse's observation of later periods in central Australia, where the 'securing of invaded property' was characterised by 'murderous campaigns [and] lawlessness' (Rowse 1998). The evidence for 'murderous campaigns' does not exist for Strangways Springs Station - nor would it necessarily be found in written accounts - yet there was forceful maintenance of the pastoral domain, and protection of Aboriginal participants within it. Over time, European concerns about Aboriginal activities decreased, and the system of rationing seems to have been central to the medium-term stability of cross-cultural relationships.

\section{Full-time male and female workers}

The Europeans describe only a handful of Aboriginal workers during the period 1860-1900. Here I provide two biographies - of Kalli Kalli and Annie.

Records of Kalli Kalli provide an insight into crosscultural engagements between the station manager and Aboriginal workers, and the indoctrination of Aboriginal children into the pastoral domain. In 1908, Oastler recalled him in the early $1860 \mathrm{~s}$ :

My boy Kalli Kalli, whom I found starving, without parents, at eight years of age, equipped with a small boomerang and yam stick in search for lizards, mice and rats for food with the proviso that should he kill anything extra good it must be taken into the camp for the old men, the inferior articles only being allowed to the youngsters. This being part of their religion it was strictly adhered to, but being in contact with civilisation the aboriginal mind does not carry out this order to the present day. So I gave poor Kalli Kalli a share of my dinner that I happened to have with me, and I adopted him of the spot, and kept him as my henchman for many years... and I am happy to say he has proved useful in many ways, being even able to take a contract on his own account, and I assure you it was a great pleasure for me to shake hands with my boy, Kalli Kalli, now a grey haired man on the shady side of forty, who had ridden in. forty miles to say goodbye to 'Mootabata' when I left the station a short time ago. (Oastler 1908)

Pastoralists' training of Aboriginal children is rarely described in the annals of colonial Australia. The evidence reported here indicates that child indoctrination was part of the pastoral system, although further research is required to better understand the extent of this practice. At Strangways Springs Station Aboriginal children became senior trusted workers, providing valuable linguistic and cultural knowledge. Kalli Kalli's experience was similar to most 'henchmen'. He worked as a shepherd and was a skilled horse breaker. He was a drover, at least once travelling $1000 \mathrm{~km}$ south to Springfield Station where, as a young boy, John Warren recalled "black stock men...would come down from the station with a mob of cattle or sheep - what heroes we thought them" (NLA, MS 6120, The Four Warrens). Kalli Kalli worked on outstations, sometimes with Europeans, often 
just with his family and other Aboriginal workers. In the first phase of pastoralism, before fences. Kalli Kalli and others often tracked lost sheep and horses. Accounting indicates that - unlike the white workers - Aboriginal workers were never paid cash, but rations. (The only exception at Strangways Springs was a man named Tilbrook, who appears to have arrived with the pastoralists as a seasoned worker, and was not from the Lake Eyre region.)

Kalli Kalli represents how indigenous workers existed between two worlds. For example, in the 1860 s when an Aboriginal shepherd was to be executed by a revenge expedition, Oastler describes how several small Aboriginal-run outstations were solely defended by himself and Kalli Kalli. Oastler states that he fired warning shots at the armed group, and employed Kalli Kalli to "follow on horseback... and hours later he returned with the information: 'Yes, him pull further away more further"' (Oastler 1860s). Yet Kalli Kalli was also required to participate in local ceremonial life initiated by 'strangers'. For example, in 1866:

some Wild Blacks came have taken our boy Kalli to cut him. He screamed to me for assistance...I would have fired into them at once but I considered I had no right to interfere in their religious ceremonies. Jacky, our ram shepherd, Kalli's sister and all our useful washing blacks have gone to see the operation. I don't expect to see them back for a week. (Jeffreys 27 May 1866)

In the historic accounts, certain Aboriginal people such as Kalli Kalli were described as companions for the Europeans who, more often than not, would be the only white men. With their experience and proven abilities these Aboriginal workers remained important to the pastoralists. As they grew up the pastoral system changed, as did their work. For example, after the 1880 s Kalli Kalli was no longer a shepherd, and he had shifted his work and that of his greater family to hunting and fencing. He is pictured at that time in the Pictorial Australian (Figure 4), the article stating, "Kalli Kalli has a monopoly of the Anna Creek fencing, and he does it well" (February 1891:30).

The second example concerns Annie, described as Kalli Kalli's sister. Colonial-era pastoral work is overwhelmingly represented as male activity: in the earlier quotes by Bean (1912) and Collier (1911) their shepherds are male and white. On this pastoral frontier there were few European women, yet 1860s letters reveal that - particularly during the labour intensive, shepherding-based, first phase of pastoralism - there were female Aboriginal shepherds. Eighteen months after Strangways Springs Station's inception, Jeffrey's describes the care of fly-bitten cattle and horses, when he:

gave them in charge to Annie, Kalli Kalli's little sister, one of the little shepherdesses. She looks after them with great care and musters them every day to a rain water hole three miles from here [Strangways Springs headstation]. (Jeffreys 5 March 1866)

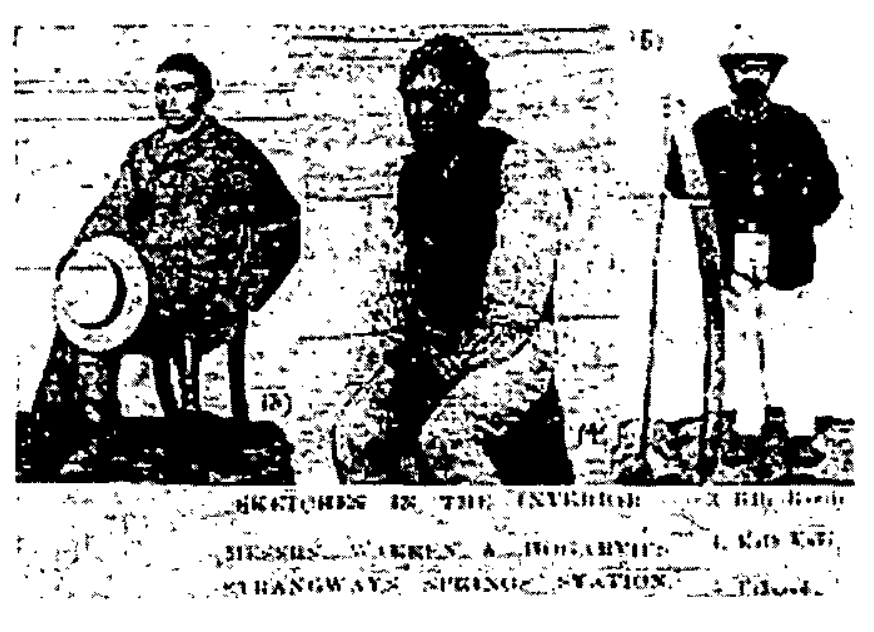

Figure 4. From left: Billy Rowdy, Kalli Kalli and Tilbrook (Pictorial Australian Feb. 1891:21. Photograph by Hon. J. Warren).

The named shepherdesses were only some of the women workers, whose shepherding work, like the Aboriginal men, was with either white workers or solely in Aboriginal-run camps. Some accounts suggest outstations run solely by women when, on occasion, the Aboriginal males left an outstation for a ceremony. It would appear women were also indoctrinated to pastoral work as youths, for during the first decade of the station the women are described as 'children' and 'little'. They were trusted workers. When the white workers Jeffreys and King were blinded by ophthalmia:

Fortunately one of the little shepherdesses was at hand. I gave the flock into her charge... After stopping four days I felt so ill I got a little shepherdess to get two horses although she never rode before. She rode one horse and led the one I rode and brought me safely home. I left the flocks to her cousin. (Jeffreys 16 April 1866)

As well as assisting with large flocks of sheep at outstations women's work commonly included herding smaller flocks of goats, fine-wool sheep, rams, and sheep intended for rations - these smaller flocks were nearly always located close to the head-station. The only two white women referred to in the first pastoral phase also herded these flocks.

A brief observation on references to families is necessary. Despite a paucity of references to Aboriginal families in the European documents, it is assumed that the existence of named Aboriginal workers indicates the existence of nearby families, both at the main station camp and at outstations. This is different in later periods; for example, in the twentieth century government agencies attempted to report the size of Aboriginal camps on central Australian pastoral properties (Gill and Paterson forthcoming). The presence of families was presumably important during cross-cultural negotiations, as explored below. 


\section{The texture of agency}

To explore the significance of this evidence the following discussion considers first, how the historical and the archaeological evidence each contribute to an understanding of agency at Strangways Springs and second, the implication of this research for studies of cross-cultural engagement.

Despite providing insight into Strangways Springs station the historical sources are limited, as suggested above regarding historic references to families. The texts suggest a small core group of male and female Aboriginal workers who assisted in the negotiations with a greater body of unnamed Aboriginal workers whose seasonal work was necessary for an economically successful pastoral domain. However, unnamed individuals are more difficult to quantify. The sole use of named individuals in a reconstruction of the makeup of the work force would be misleading. The ratio of named black to white workers is $2: 9$, while a different ratio of black to white - based on descriptions of the number of workers required at outstations during labour-intensive work - is $4: 1$. Thus, the majority of Aboriginal involvement in the station - eighty percent of the workforce - falls outside historic description.

The strength of the historic accounts of Aboriginal workers at Strangways Springs is in demonstrating different forms of indigenous involvement in the pastoral domain. The biographies of Kalli Kalli and Annie allow insight into the most permanent of indigenous workers. Ian Hodder promotes such a biographical approach to demonstrate individual versus group agency:

It is rare that archaeologists can identify named individuals: it is rare that they can piece together anything approaching a full account of an individual life. Yet we routinely have evidence of fragments of lives. The challenge is to build up these fragments into the fullest possible accounts of individual lived lives, by grouping together events and sequences of events wherever possible. (Hodder 2000:26)

While Hodder is discussing archaeology in its broadest time sense, in this study the historic sources sometimes available to historical archaeologists prove particularly useful. What are the implications of this evidence for an archaeological study? Specifically, how does this documentary evidence of Strangways Springs - of a quality rare for colonial Australia - relate to the archaeological record? The actions of individuals are difficult to isolate archaeologically, but individual acts, such as reduction sequences in making glass tools, do occur. More common are records of repeated and group behaviour. In the sites described here there is rarely any stratigraphy and, in being short term, it is difficult to determine change over time. Nonetheless using archaeological material it has been possible to define two phases in the pastoral landscape over time, each of which had ramifications for the location and organisation of Aboriginal and European workers.
Additionally, the archaeological record suggests longterm trajectories in Aboriginal society extending into the contact era, as early historic period Aboriginal subsistence would appear, in a very broad sense, to correlate with pre-contact patterns (Paterson 2000a). Over time sites shifted and site content changed according to the level of the inhabitants' involvement in the pastoral domain and degree of access to rations. This accords with archaeological research of contact era situations elsewhere; these studies have measured trajectories in indigenous life extending from before contact with outsiders, which requires longer time frames than are often used in historic-period studies (Mulvaney 1989:xvi; Lightfoot 1995; Torrence and Clarke 2000; Paterson 2002). In the south-western Lake Eyre Basin the sites of culture contact were in Aboriginal country; using oral testimonies for northern Australia, Baker (1999) critiques the perception of Aboriginal people 'coming in' by emphasising that European people 'went out' and established their early settlements at places that were the focus of Aboriginal life (1999:160). A difficulty for archaeologists has been the reliance on newly available material culture at contact to identify Aboriginal activity (Spector 1993; Colley and Bickford 1996; Torrence and Clark 2000), which risks missing broader cultural transformations. This problem has been best tackled in regional studies focussing on human behaviour in landscapes over longer periods of time (Lightfoot 1995; Clarke 2000).

Strangways Springs is a network of related sites headstation, outstations and other work sites - which are key locales for individual and group behaviour. These sites are modified British pastoral sites in an Australian landscape, yet also reflect Aboriginal knowledge and participation with the pastoralists. They are places that were built by white and black people. The sites are working and residential locales for family groups, as well as white and black individual workers. The archaeological record of huts and campsites is complemented by assemblages of imported goods reflecting patterns of trade, commerce and communication whether ochres imported by Aboriginal trading parties or English ceramics transported by bullock drays from Adelaide (which was barely two decades old). Work sites are gendered places. The post-contact sites are places of age differentials, with a range of younger workers (male and female) trusted by the white pastoralists. They also represent power differentials as places where the insider/stranger distinction was real. Archaeological correlates of this are broadly reflected in assemblage richness, a simple measure of access to goods available within the pastoral domain.

Work sites are places of economic shifts in Aboriginal subsistence. For example, over time there appears to be a reduction - then absence - in seed grinding equipment (Paterson 2000a), particularly at campsites at Strangways Springs. This may reflect access to new rationed foods. (This analysis takes into account fragmented grinding equipment, since unbroken ones were often collected 
later.) For women, potentially, time was freed for other work. Some exotic items, such as fine-grained chert common to pre-contact settlements, are rarely present in pastoral work sites. Presumably materials such as modified metal blades and glass flakes, which occur extensively in post-contact sites, replace stone. However, other regionally traded items, such as the Flinders Ranges ochre, remained important for several years into the contact era.

The material remains described here have both practical and symbolic functions. They are the material reflection of individuals and groups of people (which were meaningful units, such as individuals and family, or white and black), of economic behaviour, of subsistence (established and new) and of regional behavior (such as trade and communication). These reflect short-term process (such as an outstation used only once), annual processes (such as seasonal subsistence and pastoral work) and long-term processes (from changes over decades in pastoralism, to changes in Aboriginal life resulting from British colonialism, and indeed individual immigrants' life as a result of establishing animal husbandry in this environment for the first time).

The synthetic analysis demonstrates a distinct inverse relationship for material and documentary records in terms of levels of agency (Figure 5), coupled with a general trend for historic sources to be temporally precise and spatially inexact, while the converse is often true for the archaeological record. This condition suggests that the analytic use of agency needs to accommodate both individuals and groups. Again, it is true that studies of recent human contexts more easily illustrate the internal diversity of groups - rather than 'faceless blobs' (Gero and Conkey 1991) — without necessarily specifically identifying individuals. This case study has tried to demonstrate past agency in relation to cultural distinctions such as age, gender, power, and knowledge. In other words, this study attempts to bridge group-level agency (Wobst 2000) and real historical actors (Hodder 2000).
Interest in the interplay of individuals and structures has a long history, particularly for archaeologists and historians raising questions about short-term events and long-term processes. What then can be said about the brief events considered in this case study? What was driving behaviour and decision-making? To address this requires considering the two broad historical trajectories that meet here - Aboriginal and British.

In this context-specific study - which is most informative about the world 'within' the pastoral domain the presence of new material culture, adoption of pastoral-related work practices, shifts in subsistence and settlement patterns, are accompanied by the maintenance of local cultural continuity. Cultural practices and trade are, at least initially, maintained across the permeable boundary of the pastoral domain. However, the imported industry, law and power of the pastoralists appear to have restricted access of 'traditional' country to those most closely involved with the pastoralists. The evidence for this is found in the pastoralists' letters; for example they describe outstation workers armed with revolvers and intimidating 'strangers'. To comprehend the processes of cultural engagement requires interpreting the central structuring principles, such as the organisation of the pastoral industry and the role of rationing, which created a workable hybrid society as a basis to a stable and economically successful colonial-era domain. Despite focussing in this paper on the Aboriginal side of the contact story, clearly the British importation and adaptation of economic activities, society and power structures are the flipside.

At Strangways Springs, the central things learned and developed by the Europeans are pastoralism and rationing. The modification of the pastoral domain over time, characterised by a distinctive archaéological fingerprint, is related to broader issues such as: regional, national and international demand for sheep, then cattle, products; technological developments; the stability of the pastoral domain; and the regional infrastructure accompanying European colonisation of central and northern

\begin{tabular}{ccc} 
Quality of evidence & Historic record & $\begin{array}{c}\text { Archaeological record } \\
\text { (All people) }\end{array}$ \\
\hline Good & European pastoralists & Use of material culture \\
Loor & Aboriginal People & $\begin{array}{c}\text { Location of activity } \\
\text { Individual behaviour } \\
\text { (activity area/assemblage) }\end{array}$ \\
$\begin{array}{c}\text { Group behaviour } \\
\text { (activity area/assemblage) }\end{array}$
\end{tabular}

Figure 5. Model of the relationship between historic and archaeological evidence for forms of agency (modified from Kent 1984:13, fig.1). 
Australia. From the earliest days of Strangways Springs Station, and increasingly over time, the pastoralists 'learned' rationing, in this case to define local residential groups as both permanent and seasonal work forces. This was not new, rationing was part of Australian colonial life from 1788, and already part of pastoral life for both white and black workers. Importantly, rations provided by the colonial administration augmented pastoral rations, and re-enforced the primacy of the headstation in the landscape. Also, given the potential for cross-cultural misunderstanding, the transfer of rationed goods for labour did not require congruity of understanding between donors and receivers (Rowse 1998:5). The practice of providing rations rather than fair wages reflected inequities between Aboriginal workers and European station owners that continued for over a century after the pastoral settlement of central Australia began (see May 1994; Reynolds 1972; Rose 1991; Rowley 1971; Rowse 1998; Watson 1998).

Rationing encouraged indigenous mobilisation to form large camps of workers. Hamilton described this in ecological terms as a 'super waterhole' where Aboriginal people 'moved towards the whites, not in order to take part in white society, not in order to experience social change, but in order to eat their food' (1972:41). However, beyond this exist social parameters. Not all Aboriginal people in these camps were equal in terms of access to, and knowledge of, the whites. Some had specific responsibilities to the pastoralists in addition to their own society. The social ramifications were that rationed camps provided ceremonial opportunity (as described above for initiation), which Rowse describes as 'ceremonial momentum' (1998:78-9). This type of internal and cross-cultural complexity has been demonstrated for twentieth century contexts (May 1994; Rose 1991; Rowse 1998; Watson 1998) but is less clear for earlier colonial periods.

Presumably, a range of pre-existing social institutions and practice - such as power and prestige structures, survival tactics, social distinctions such as kinship, and location of one's country - were important to crosscultural engagement. For example, Myers (1986) described how, for nearby Pintupi in the twentieth century, authority was structured through nurturance, which facilitated bonds between pastoralists and Aboriginal workers, and where older men were the chief negotiators for work and sexual favours. In a similar vein, Rowley (1971:211) described Aboriginal involvement in pastoral stations as 'forced adjustment' to a 'state of paternal rule' (see also Hartwig 1965; Baker 1999). However, at nineteenth century Strangways Springs the pastoralists never refer to the older men or women just the younger as described above. This requires further research, since the potential existed for sustained contact between older Aboriginal people and the pastoralists, despite not being described by the pastoralists. The tendency over time seems to be for a focus of Aboriginal settlement at the head station, characterised by extensive separate campsites out of sight, but within three kilometres, of the whites. This settlement pattern may in part result from rationing older members of the society, as suggested by colonial rationing policies, while younger members were involved in the more dispersed station work (remembering that some flocks were stationed at the headstation, such as those herded by certain Aboriginal women).

\section{Conclusion}

This case study has focused on differential forms of cultural interaction, varying according to a range of circumstances such as time period, location, season, climate, individual decisions and opportunities, pastoral practices, work roles and responsibilities, and access to rations. I have avoided simplistic oppositional models for cultural interaction to better accommodate past different behaviours.

In 1896 E.C. Stirling, the anthropologist on the 1894 Horn Scientific Expedition, wrote of his wish to access the memories of 'those early pioneers and settlers who for years lived in close association with the natives at a time when their customs were still uninfluenced by general contact with the Europeans' (Stirling 1896, cited in Rowse 1998:16). Archaeological studies of cross-cultural interaction between Aboriginal Australians and non-indigenous settlers provide an account of historic events periods such as those desired by Stirling (and in addition fresh perspectives on archaeological approaches to historical and indigenous archaeology).

This case study of agency has relied on historical sources which are not available for most past human societies, and which represent an opportunity for historical archaeologists. The primary sources used are probably richer than for most other nineteenth century Australian contexts of culture contact and generate a better understanding of archaeological evidence, both in the case study and more broadly. The synthetic analysis suggests differential degrees of Aboriginal involvement in the nineteenth century pastoral domain, which encourages research into three aspects: the internal stratification of past societies often made difficult by some culture-contact theories; the means and consequences of different Aboriginal roles and actions in colonial society; and the Aboriginal contribution to colonial-era industries.

\section{Acknowledgements}

I am grateful to all those who assisted in fieldwork in the Lake Eyre Basin during 1995-1998, and assistance from the staff and students at the University of Sydney and the Australian National University. The research was funded by the Carlyle Greenwell Bequest (University of Sydney) and Pembroke School (Adelaide). I am grateful for editorial comments from Nicholas Cheesman, Sandra Bowdler, Jennifer Heigel, Peter White and an anonymous reviewer. 


\section{References}

Baker, R. 1999. Land is Life: From Bush to Town. The Story of the Yanyuwa People. Allen \& Unwin, St Leonards.

Basedow, H. 1920. Report upon the Third Medical Relief Expedition among the Aborigines of South Australia. Manuscript, National Museum of Australia, Canberra.

Bean, C.E.W. 1910. On the Wool Track. Sirius Books, Sydney.

Clarke, A. 2000. Time, Tradition and Transformation: the negotiation of cross-cultural engagements on Groote Eylandt, northern Australia, northern Australia. The Archaeology of Difference: Negotiating cross-cultural engagements in Oceania, edited by R. Torrence and A. Clarke:142-181. Routledge, London.

Colley, S. and A. Bickford. 1996. 'Real' Aboriginals and 'real' archaeology: Aboriginal places and Australian historical archaeology. World Archaeological Bulletin 7:5-21.

Collier, J.B. 1911. The Pastoral Age in Australasia. Whitcombe and Tombs, London.

Davidson, I. 1983. On the edge of the Simpson: recent additions to the understanding of prehistoric artefact distributions in arid Australia. Australian Archaeology 16:27-37.

Dobres, M. and Robb, J. (eds) 2000. Agency in Archaeology. Routledge, London.

Dornan, J.L. 2002. Agency and Archaeology: Past, Present, and Future Directions. Journal of Archaeological Method and Theory 9, 4:303-329.

Elkin, A.P. 1934. Cult totemism and mythology in north-eastem South Australia. Oceania 5, 2:187-189.

Florek, S. 1993. Archaeology of the Mound Spring Campsites near Lake Eyre in South Australia. Unpublished PhD thesis, University of Sydney.

Gero, J.M. and Conkey, M.W. (eds) 1991. Engendering Archaeology: Women and Prehistory. Blackwell, Oxford.

Gill, N. and Paterson, A. forthcoming. 'Murphy, do you want to delete this?' Hidden histories and hidden landscapes in the Murchison and Davenport Ranges. In Ward, G. (ed) Power of Knowledge and the Resonance of Tradition: AIAT. SIS Conference 2001. Aboriginal Studies Press, Canberra.

Gill, N., Paterson, A. and Japanangka Kennedy, M. 2002. Hidden landscapes. In Cultural Survival Quarterly 26, $2: 37-38$.

Gregory, J.W. 1906. The Dead Heart of Australia. A Journey around Lake Eyre in the Summer of 1901-1902, With Some Account of the Lake Eyre Basin and the Flowing Wells of Central Australia. John Murray, London.

Hamilton, A. 1972. Blacks and whites: the relationships of change. Arena 30:34-48.

Hartwig, M.C. 1965. The Progress of White Settlement in the Alice Springs District and its Affect on the Aboriginal Inhabitants, 1860-1894. Unpublished PhD thesis, University of Adelaide.

Hercus, L.A. 1971. Arabana and Wangganguru Traditions. Oceania 42, 2:94-109.

Hercus, L.A. 1980. 'How we danced the Mudlunga': memories of 1901 and 1902. Aboriginal History 4:5-32.

Hercus, L.A. \& Clarke, P. 1986. Nine Simpson Desert wells. Archaeology in Oceania 21:51-62.

Hodder, I. 2000. Agency and individuals in long-term process. Agency in Archaeology, edited by M. Dobres and J. Robb: 21-33. Routledge, London.

Howitt, A.W. 1859. Diary kept by A.W. Howitt on journey to Davenport Range Sept. 21, 1859 to Oct. 31, 1859. In MS 9356 14a and 14b, 'A.W. Howitt Papers: Incomplete letters; misc. material'. La Trobe Library, Melbourne.

Howitt, A.W. [1908]1996. The Native Tribes of Southeast Australia. Aboriginal Studies Press, Canberra.

Hughes, PJ. 1981a. Olympic Dam project: regional testing of the baseline archaeology predictive statement. Report to Kinhill Stearns, Adelaide.

Hughes, PJ. 1981b. Olympic Dam project: an archaeological survey of the Whelan Shaft area. Report to Kinhill Stearns, Adelaide.

Hughes, P.J. \& Hiscock, P. 1981. Olympic Dam project: baseIine archaeological study. Report to Kinhill Stearns, Adelaide.

Hughes, P.J. \& Lampert, R.J. 1980. Pleistocene occupation of the arid zone on southeast Australia: research prospects for the Cooper Creek-Strezlecki Desert region. Australian Archaeology 10:52-67.

Hughes, P.J. \& Lampert, R.J. 1985. Cultural and natural heritage survey of mound springs in South Australia: assessment of Aboriginal archaeological significance. Report to Kinhill Stearns, Adelaide.

Kirch, P. and Sahlins, M. 1992. Anahulu: The Anthropology of History in the Kingdom of Hawaii. University of Chicago Press, Chicago.

Lightfoot, K. 1995. Culture contact studies: redefining the relationship between prehistoric and historic archaeology. American Antiquity 60, 2:199-217.

Lourandos, H. 1997. Continent of Hunter-Gatherers: New Perspectives in Australian Prehistory. Cambridge University Press, Melbourne.

May, D. 1994. Aboriginal Labour and the Cattle Industry: Queensland from White Settlement to the Present. Cambridge University Press, Melbourne.

McBryde, I. 1987. Goods from another country: exchange networks and the people of the Lake Eyre Basin. Australians to 1788, edited by J. Mulvaney and J.P. White:253-73. Fairfax, Syme and Weldon, Sydney.

McGrath, A. 1987. 'Born in the Cattle': Aborigines in Cattle Country. Allen and Unwin, Sydney.

Mulvaney, D.J. 1989. Encounters in Place. Outsiders and Aboriginal Australians 1606-1985. University of Queensland Press, St Lucia.

Myers, J. 1986. Pintupi Country, Pintupi Self: Sentiment, Place and Politics among Western Desert Aborigines. Smithsonian Institution, Washington.

Oastler, J. 1908. The Honorary Magistrate, vol. 1904-1907:208-9. Mortlock Library of South Australiana, Adelaide.

Paterson, A. 2000a. Confronting the sources: The archaeology of culture-contact in the south-western Lake Eyre Basin, Central Australia. Unpublished PhD thesis, University of Sydney.

Paterson, A. 2000b. Situating Belonging: The role of historical archaeology in locating cultural relationships using examples from Australian pastoral domains. Balayi: Culture, Law and Colonialism 2:109-131.

Paterson, A. 2002. Australian Aboriginal Archaeology. In Orser, Charles E., (ed.) Encyclopedia of Historical Archaeology:38-42. Routledge, London.

Paterson, A. 2003 forthcoming. Early pastoral landscapes and culture contact in Central Australia. Historical Archaeology.

Reynolds, H. (ed) 1972. Aborigines and Settlers. Cassell, North Melbourne.

Rose, D.B. 1991. Hidden Histories: Black Stories from Victoria River Downs, Humbert River and Wave Hill 
Stations. Aboriginal Studies Press, Canberra.

Rowley, C.D. 1971. Outcasts in White Australia: Aboriginal Policy and Practice (Volume II). Australian National University Press, Canberra.

Rowse, T. 1998. White Flour, White Power: From Rations to Citizenship in Central Australia. Cambridge University Press. Cambridge.

Smith, M.A. 1987. Pleistocene occupation in arid Central Australia. Nature 328:710-11.

Smith, M.A. 1989. The case for a resident human population in the central Australian Ranges during full glacial aridity. Archaeology in Oceania 24:93-105.

Spencer, B. \& Gillen, F.J. 1899. Native Tribes of Central Australia. Macmillan, London.

Spencer, B. \& Gillen, F.J. 1912. Across Australia. Macmillan, London.

Spector, J.D. 1993. What This Awl Means: Feminist Archaeology at a Wahpeton Dakota Village. Minnesota Historical Society Press, St. Paul.

Stirling, E.C. 1896. Anthropology. Report on the Work of the Horn Scientific Expedition to Central Australia (vol 4), edited by B. Spencer:1-157. Melville, Mullen and Slade. Dalau and Co., Melbourne.

Strang, V. 1999. Competing perceptions of landscape in Kowanyama, North Queensland. The Archaeology and Anthropology of Landscape, edited by P.J. Ucko and R. Layton:206-18. Routledge, London.

Stuart, J.M. 1865. The Journals of John McDouall Stuart: Expeditions in Australia During the Years 1858, 1859, 1860, 1891, and 1862. (second edition). Saunders, Otley and Co., London. Facsimile edition No. 198, Libraries Board of South Australia, Adelaide.

Torrence, R. and Clarke, A. (eds) 2000. The archaeology of difference: negotiating cross-cultural engagements in Oceania. London, Routledge.

Veth, P. 1989. Islands in the interior: a model for the colonisation of Australia's arid zone. Archaeology in Oceania 24:81-92.

Veth, P. 1993. Islands in the Interior: The Dynamics of Prehistoric Adaptations within the Arid Zone of Australia.
International Monographs in Prehistory, Ann Arbor, Michigan.

Warburton, P.E. 1988. An Expedition North-East and NorthWest of Lake Eyre: The Diary and Despatches of Major Warburton, Commissioner of Police, 1866. Sullivan's Cove, Adelaide.

Wasson, R. 1986. Geomorphology and Quaternary history of the Australian continental dunefields. Geographical Review of Japan 59:55-67.

Watson, P. 1998. Frontier Lands and Pioneer Legends: How Pastoralists Gained Karuwali Land. Allen and Unwin, St Leonards.

Warren, J. Four John Warrens: 1838-1930: Recollections of Pioneering in Australia - by Number Three (John Warren). Manuscript 6120, National Library of Australia, Canberra.

Wobst, H. 2000. Agency in spite of material culture. Agency in Archaeology, M. Dobres and J. Robb:40-50. Routledge, London.

\section{Archival material}

SAPP (South Australian Parliamentary papers). 1858, 1, No. 25: Northern Explorations: Reports etc of Explorations.. by Babbage, Warburton, Geharty and Parry.

State Records of South Australia: Protector of Aborigines Letterbook. GRG 52/7.

State Records of South Australia: Aboriginal Affairs Correspondence Files. GRG 52/1.

State Records of South Australia: Police Station Strangways Springs Joumal From April 12 April 26 1886-1888. GRG $5 / 5 / 314$.

State Records of South Australia: Police Department Records, GRG 5.

The Pictorial Australian, February 1891.pp. 21, 28, 30 Strangways Springs Station. Mortlock Library of South Australiana, Adelaide.

Warren Papers, Public Record Group 27, Mortiock Library of South Australiana, Adelaide. 